Ann. Biol. anim. Bioch. Biophys., 1976, 16 (I), 25-36.

\title{
PURIFICATION OF GONADOTROPIN FROM RAINBOW TROUT (SALMO GAIRDNERII RICHARDSON) PITUITARY GLANDS
}

\author{
B. BRETON, B. JALABERT et P. REINAUD \\ Laboratoire de Physiologie des Poissons, \\ Centre national de Recherches zootechniques, I. N.R. A., \\ 78350 Jouy en Josas
}

\begin{abstract}
SUMMARY
A method of purifying trout gonadotropic hormone is discussed. The technique consists of the following stages : alcoholic extraction, two successive gel filtrations on Sephadex G-50 and G-IOo, chromatography on DEAE-cellulose and ultrogel ACA54. The biological activity of fractions obtained is measured using as assay the maturation in vitro of trout oocytes.

The preparation obtained has a molecular weight of about 27500 , determined by behavior on Sephadex-G Ioo and analytical ultracentrifugation for a $\mathrm{KS}_{20} \mathrm{~W}$ of 2.45. Polyacrylamide gel electrophoresis shows two strips of electrophoretic mobility, 0.50 and 0.58 . Analysis of the amino acid composition of the preparation indicates a number of I60 AA residues per mole.

These different values are compared to the corresponding ones for c-GtH, s-GtH and mammalian gonadotropins.
\end{abstract}

\section{INTRODUC'TION}

The purification of fish gonadotropin has encountered a major problem up to now, namely, a lack of sufficiently sensitive and specific biological assays for a given species (FONTAINE et al., I972; BRETON et al., 1973). However, a Carp pituitary gonadotropin (c-GtH) has been prepared for the first time in a highly purified state by BURZAWA-GERARD (197I) using the frog spermiation assay, criteria of little specificity. The same assay was also used by GoNDCHARov (I972) to prepare sturgeon GtH, while Donaldson et al. (1972) employed a variation (Yamazaki and DonaLDSON, I968) of the goldfish gonad hydratation assay (CLEMENS et al., I964a et $b$ ) to obtain gonadotropic hormone from salmon pituitary. In all cases, gametogenesis promoting activity in fish was only controlled a posteriori (BILLARD et al., I970 ; Donaldson et al., I972 ; SUndararaj et al., 1972).

In the present work, the purification of a rainbow Trout gonadotropin was undertaken using as bioassay the in vitro intrafollicular maturation of Trout oocytes 
(to avoid species specificity), which can be considered as representative of a typical gonadotropic activity (JAL,ABERT et al., I974) since, as far as now, only one gonadotropin seems to promote both follicular growth (vitellogenesis) maturation and ovulation in fishes (Sundararaj et al., I972; Burzawa-Gerard and Fontaine, I972; BurzaWA-GERARD, I973).

\section{MATERIAI, AND METHODS}

Pituitaries were taken from adult ( 3 years minimum) rainbow trout during spawning.

The following preparation techniques were used :

- alcohol extraction according to ScHmint et al. (I965);

- gel filtration on Sephadex G-5o and G-roo ; gradient ;

- ion-exchange chromatography on DEAE-cellulose Whatman DE 23 with ionic force

- chromatography on agarose acrylamide gel ACA54 (I. B. F. ultrogel commercialized by L.KB France) ;

- concentration of protein solutions between each purification stage was done on Amicon UM 05 membrane in a Diaflo chamber under nitrogen pressure, followed by equilibrium dialysis against the proper buffers for subsequent chromatography;

- protein concentration of chromatographic effluents was determined by Folin reaction using the technique of LowRy et al. (195I).

The preparations obtained were analyzed using the following physico-chemical techniques :

- determination of electrophoretic mobilities by polyacrylamide gel electrophoresis in 8 p, roo gel, using ORNSTEıN's technique (1964), and Isco gel scanner reading;

- study of comportment on Sephadex G Ioo (exclusion volume-molecular weight), according to LAURANT and KillandeR's technique (1964);

- analysis of ultraviolet absorption spectra on a Carry spectrophotometer ;

- measurement of sedimentation coefficient $\mathrm{KS}_{20} \mathrm{~W}$ and molecular weight (equilibirium sedimentation) by analytical ultracentrifugation (Beckman Spinco analytic ultracentrifuge, Model E, equipped with an ultraviolet scanning device) ;

- analysis of amino acid composition after 24 -hours acid hydrolysis with $\mathrm{HCl} 6 \mathrm{~N}$ at $\mathrm{I} 10^{\circ} \mathrm{C}$. Free amino acid assay was done using the technique of Moore et al. (1958) with a Beckman r $20 B$ analyzer for preparation I, and Menkzo's technique (I973) with an Optica aminolyzer for preparation 2 .

\section{RESULTS}

\section{I. - Alcohol extraction}

Immediately after collection, pituitaries are frozen into liquid nitrogen, lyophilized and reduced to acetonic powder, according to the technique described for mammalian glycoprotein hormones by CoURTE (I970).

The acetonic powder is then extracted for 24 hours at $4^{\circ} \mathrm{C}$ with a solution $40 \mathrm{p}$. IOO ethanol and $2 \mathrm{p}$. IOO NaCl, (IOO $\mathrm{ml}$ of solution for $2.5 \mathrm{~g}$ of acetonic powder). After 20 minute centrifugation at $5500 \mathrm{~g}$, the precipitate is extracted twice again in the same volume of alcoholic solution. The supernatants are pooled and adjusted to $\mathrm{pH} 5.2$ with glacial acetic acid, and the alcohol content brought to $85 \mathrm{p}$. roo by a slowly addition of absolute alcohol. After precipitation for 24 hours at $4^{\circ} \mathrm{C}$, the suspension obtained is centrifuged 20 minutes at $36000 \mathrm{~g}$. The dry centrifuged residue constitutes the pituitary protein extract, EPH.

In two successive year preparations the ponderal and activity yields are similar (tabl I). 
TABLE I

Ponderal and biological activity yields at different stages of $i$-GtH purification

\begin{tabular}{|c|c|c|c|c|c|c|c|c|}
\hline \multirow{2}{*}{$\begin{array}{l}\text { Prepa- } \\
\text { ration }\end{array}$} & \multirow[b]{2}{*}{ Yields } & \multicolumn{7}{|c|}{ Purification stage } \\
\hline & & $\begin{array}{l}\text { Acetone } \\
\text { powder }\end{array}$ & EpH & G-50 & G-100 & $\begin{array}{l}\text { DEAE } \\
\mathrm{C}\end{array}$ & $\begin{array}{l}\text { Ultrogel } \\
\text { ACA54 }\end{array}$ & $\begin{array}{l}\text { Overall } \\
\text { yield }\end{array}$ \\
\hline \multirow{2}{*}{1} & $\begin{array}{l}\text { mg active material } \\
\text { p. } 100 \text { ponderal yield }\end{array}$ & 2400 & $\begin{array}{c}290 \\
12.08\end{array}$ & $\begin{array}{l}117 \\
40.3\end{array}$ & $\begin{array}{c}34.18 \\
29.2\end{array}$ & $\begin{array}{l}6.72 \\
19.7\end{array}$ & & 0.28 \\
\hline & $\begin{array}{l}\text { mean activity/mg } \\
\text { p. } 100 \text { activity yield }\end{array}$ & 0.125 & $\begin{array}{c}1 \\
96.6\end{array}$ & $\begin{array}{l}2.14 \\
86.3\end{array}$ & $\begin{array}{l}5.64 \\
67.9\end{array}$ & $\begin{array}{l}2.83 \\
19.6\end{array}$ & & 6.33 \\
\hline \multirow{2}{*}{2} & $\begin{array}{l}\text { mg active material } \\
\text { p. } 100 \text { ponderal yield }\end{array}$ & 3500 & $\begin{array}{c}376 \\
10.74\end{array}$ & $\begin{array}{l}113 \\
30.0\end{array}$ & $\begin{array}{l}49.2 \\
43.5\end{array}$ & $\begin{array}{c}18.12 \\
36.9\end{array}$ & $\begin{array}{l}5.04 \\
27.8\end{array}$ & 0.14 \\
\hline & $\begin{array}{l}\text { mean activity/mg } \\
\text { p. } 100 \text { activity yield }\end{array}$ & 0.125 & $\begin{array}{c}1 \\
86.04\end{array}$ & $\begin{array}{c}3.01 \\
90.40\end{array}$ & $\begin{array}{l}5.75 \\
82.9\end{array}$ & $\begin{array}{l}6.07 \\
39.8\end{array}$ & $\begin{array}{c}8.44 \\
39\end{array}$ & 24.90 \\
\hline
\end{tabular}

\section{2. - Gel filtration on Sephadex}

EPH is fractionated by Sephadex G-50 gel filtration on a $60 \times 2.5 \mathrm{~cm}$ column with Tris- $\mathrm{HCl} 0.05 \mathrm{M}$ buffer, $\mathrm{pH} 7.8$ for the first preparation; the same buffer of o.or $\mathrm{M}$ molarity at $\mathrm{pH} 8.0$, containing $0.5 \mathrm{mM}$ dithiothreitol, is used for the second preparation.

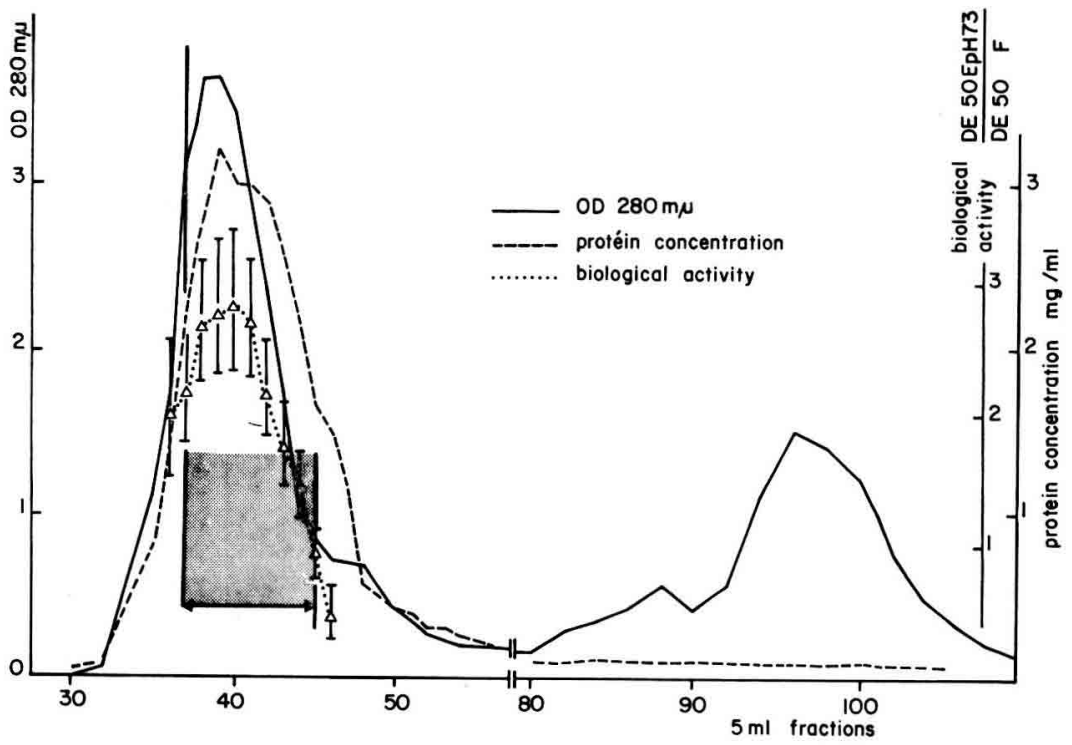

Fig. I. - Gel filtration on Sephadex G-50

(buffer Tris $\mathrm{HCl} 0.05 \mathrm{M}, \mathrm{pH} 7.8,2.5 \times 60 \mathrm{~cm}$ column)

of alcoholic extract of rainbow trout pituitary glands.

Fractions 37 to 45 were pooled for chromatography on Sephadex G-100

Vertical bars indicate the confident limits at the $95 \mathrm{p}$. roo probability level 
Figure I shows the elution diagram obtained in the first purification. Biological activity is found between fractions 37 and 45 , in the drop of the protein peak coming out in the exclusion volume of the column. Employing the second buffer system does not change the yield or biological activity.

After concentration, the active fractions are re-chromatographed on Sephadex G-IO0 in the same two buffer systems on a I00 $\times 2.5 \mathrm{~cm}$ column. Activity peaks are found between fractions 30 and 37 (fig. 2) for the first preparation ( $\mathrm{Kd}: 0.29$ ), and between 29 and 39 for the second (Kd : 0.29). In this case, yields are higher than those obtained at $\mathrm{pH} 7.8$ in absence of dithiothreitol, and there is no notable variation of mean activity per $\mathrm{mg}$ of protein.

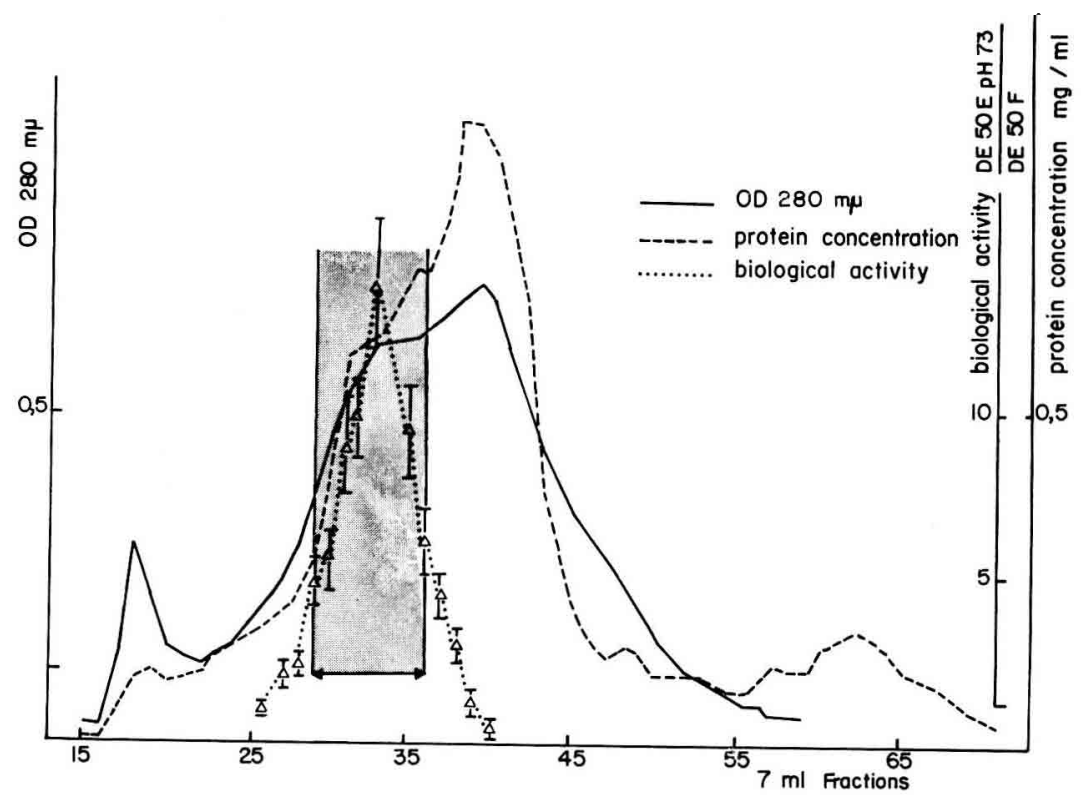

FIG. 2. - Gel filtration on Sephadex G-100

(buffer Tris $\mathrm{HCl}$ o.or M, $\mathrm{pH} 8.0$, dithiothreitol $0.5 \mathrm{mM}, 2.5 \times$ roo cm column) of gonadotropically active fractions after chromatography on Sephadex G-50.

Fractions 30 to 37 were pooled for chromatography on DEAE-cellulose

\section{3. - Chromatography on DEAE-cellulose $D E 23$}

Table 2 shows results obtained in different buffer systems of fixation and elution. Best results are obtained by using a Tris- $\mathrm{HCl}$ o.orM fixation system, $\mathrm{pH} 8.4$, containing $0.5 \mathrm{mM}$ dithiothreitol, elution is carried out using a linear gradient of the buffer and $\mathrm{NaCl} 0.5 \mathrm{M}(500 \mathrm{cc}-500 \mathrm{cc}$ ) (fig. 3). Protein yield is similar at this $\mathrm{pH}$ in absence of dithiothreitol and a shorter gradient (400-400 starting at $0.05 \mathrm{M})$. However, protein activity drops as compared to that obtained at the preceding stage (table 2). At $\mathrm{pH} 7.8$, besides loss of biological activity $(0.7 \mathrm{U} / \mathrm{ml})$, yields become very poor due to incomplete fixation ( $54 \mathrm{p}$. IOo) of active material on the ion exchanger and to considerable dilution of activity on the whole chromatogram (fig. 4). The purification of the $\mathrm{t}-\mathrm{GtH}_{1}$ is stopped at this stage. 
TABLE 2

Comparison of different chromatographic systems on DEAE-cellulose for purification of trout gonadotropin $(\mathrm{t}-\mathrm{GtH})$

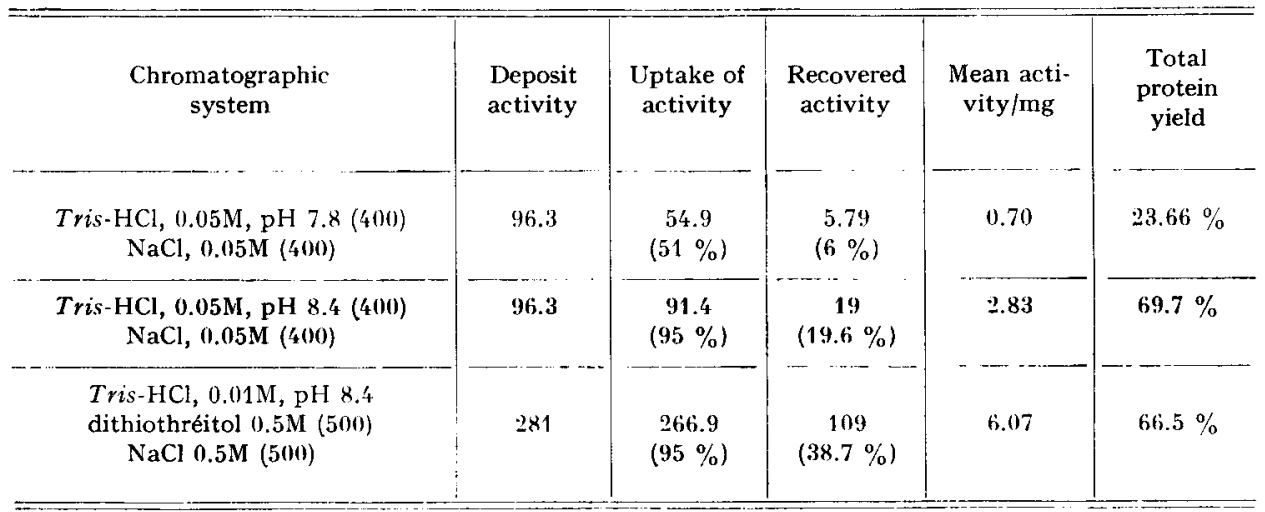

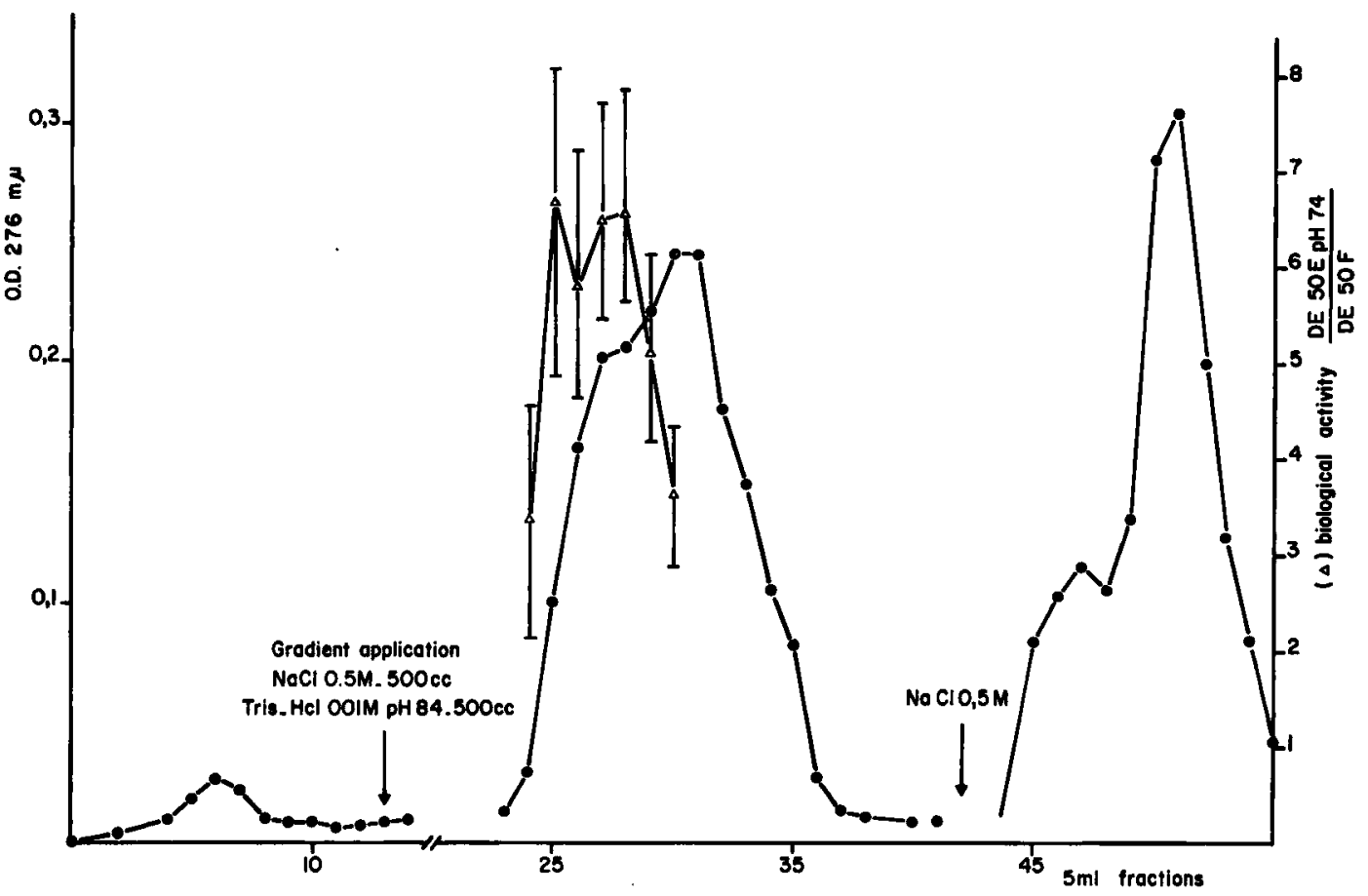

FIG. 3. - Chromatography on DEAE-cellulose Whatman DE 23 (equilibriated in buffer Tris $\mathrm{HCl}$ o.or M, pH 8.4, dithiothreitol $0.5 \mathrm{mM}$ ) of eluted gonadotropic activity after filtration on Sephadex $6-100$. Elution is done with linear ionic force gradient $(500 \mathrm{cc}$ of equilibriating buffer, $500 \mathrm{cc} \mathrm{NaCl} 0.5 \mathrm{M}$ ), $1.5 \times 25 \mathrm{~cm}$ column 


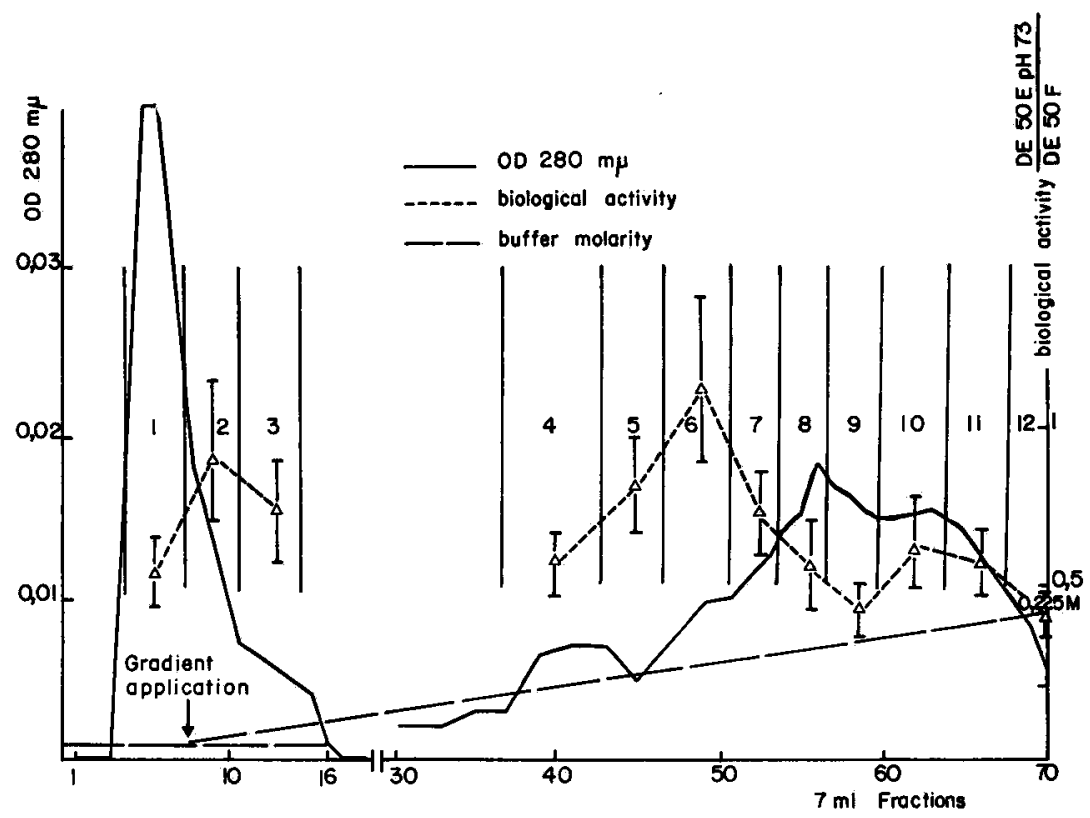

\footnotetext{
FIG. 4. - Chromatography on DEAE-cellulose Whatman DE 23 (equilibriated in buffer Tris $\mathrm{HCl} 0.05 \mathrm{M}, \mathrm{pH} 7.8$ )

of eluted gonadotropic activity after filtration on Sephadex $G-100$. Elution is done with linear ionic force gradient

(400 $\mathrm{cc}$ of buffer and equilibriator, $400 \mathrm{cc} \mathrm{NaCl} 0.5 \mathrm{M}$ ), $1.5 \times 25 \mathrm{~cm}$ column
}

\section{4. - Chromatography on ultrogel ACA54 gel}

Only $\mathrm{t}-\mathrm{GtH}_{2}$ was submitted to this chromatography in ammonium bicarbonate buffer o.orM, pH 8.o. Activity is found in the first elution peak ( $\mathrm{Kd}: 0.285$ ). No activity is found in the second peak, which includes a protein complex of about $I_{5}$ to $\mathrm{I} 7$ ooo in molecular weight (fig. 5).

Table 3 shows the plan used for purification of trout $(t-G t H)$ gonadotropin : $3500 \mathrm{mg}$ pituitary acetonic powder give $5.04 \mathrm{mg}$ active material presenting an activity gain of 67.5 , as compared to the acetonic powder.

\section{5. - Physico-chemical characteristics}

Overall results are shown in table 4 . The $\mathrm{Kd}$ and molecular weight, determined on Sephadex G-Ioo are identical for the two $\mathrm{t}-\mathrm{GtH}$ preparations and comparable to those of the c-GtH prepared by BuRzawa-GERARD (I973). On the other hand, sedimentation coefficients and molecular weight, determined by equilibrium ultracentrifugation, are different for the two trout preparations, but comparable for the $\mathrm{t}-\mathrm{GtH}_{2}$ and $\mathrm{c}-\mathrm{GtH}$. The equilibrium sedimentation peak is apparently homogenous.

In polyacrylamide gel electrophoresis at 8 p. IOO $\mathrm{pH} 9.4$ (at concentration of I $\mathrm{mg} / \mathrm{cc}$ ), the protein obtained seems to be heterogenous with two electrophoretic Rf strips $0.5^{0-58}$. 
TABLE 3

Outline of purification procedure for trout gonadotropin (t-GtH)

Pituitary glands frozen into liquid nitrogen

Treated with acetone-N butanol-ethylic ether

|

Residue extracted in 40 p. 100 ethylic alcohol -2 p. $100 \mathrm{NaCl}$

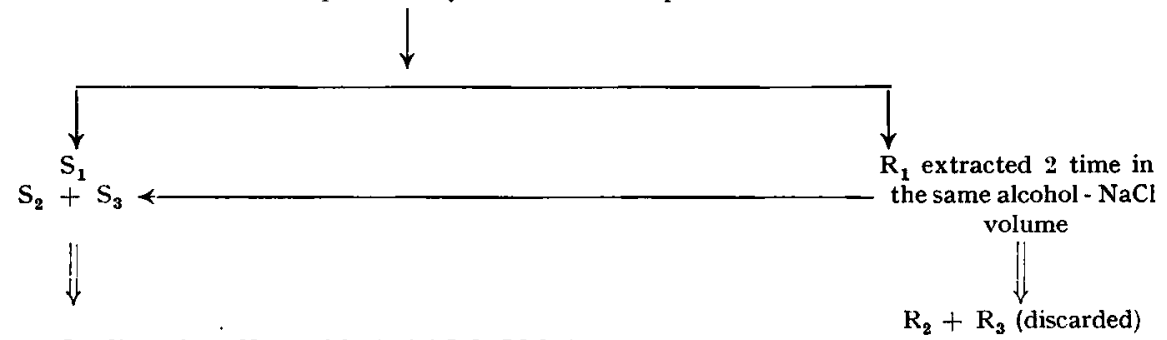

$\mathrm{S}$ adjusted to $\mathrm{pH} 5.2$ with glacial $\mathrm{CH}_{3} \mathrm{COOH}$;

$\mathrm{CH}_{3} \mathrm{CH}_{2} \mathrm{OH} 100$ p. 100 added up to 85 p. 100 alcohol saturation; centrifuged $20 \mathrm{mn}$ at $36.000 \mathrm{~g}$

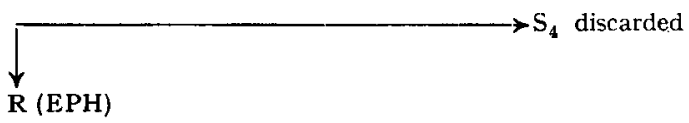

Gel filtration on Sephadex G-50; buffer Tris-HCl $0.01 \mathrm{M}$;

pH 8.0; dithiothreitol $0.5 \mathrm{mM}$

Gel filtration on Sephadex G-100 in the same buffer

Chromatographed on DEAE-cellulose DE 23 equilibriated

in buffer Tris-HCl $0.01 \mathrm{M}$; $\mathrm{pH} 8.4$; dithiothreitol $0.5 \mathrm{mM}$.

Elution by ionic force gradient, Tris $-\mathrm{HCl} 0.01 \mathrm{M}, \mathrm{pH} 8.4(500)$, $\mathrm{NaCl} 0.5 \mathrm{M}(500)$

Chromatographed on ultrogel ACA54, ammonium bicarbonate buffer $0.01 \mathrm{M}, \mathrm{pH} 8.0$

Concentration on Amicon UM 05 membrane

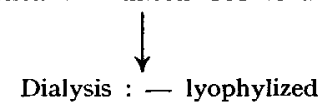




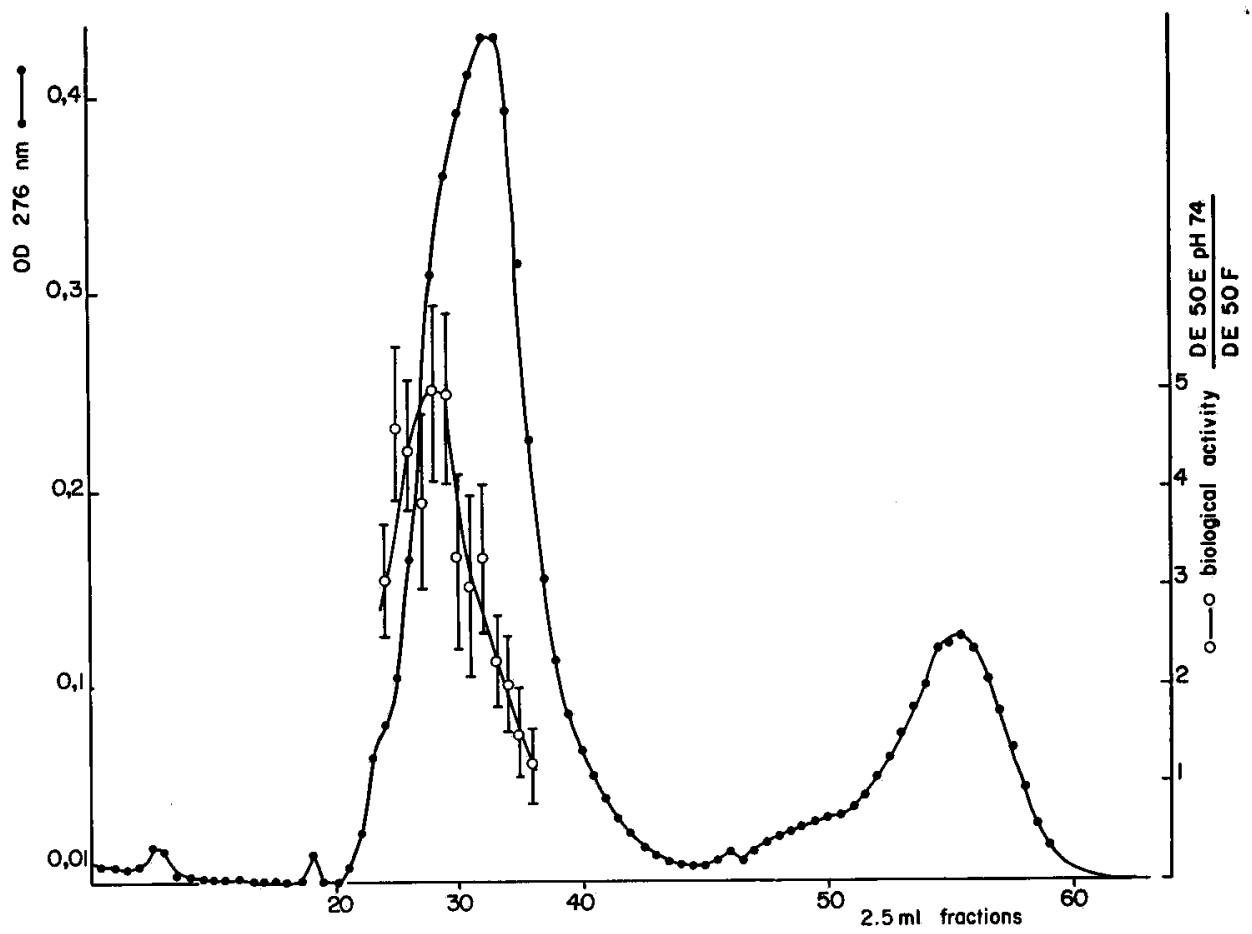

FIG. 5. - Chromatography on ultrogel ACA 54

(ammonium bicarbonate buffer o.0IM, pH 8.o, dithiothreitol $0.5 \mathrm{mM}, \mathrm{I} .5$ \% $40 \mathrm{~cm}$ column) of active fractions afler chromatography on DEAE-cellulose

TABLE 4

Comparison of physico-chemical characteristics of $t-G t H_{1}, t-G t H_{2}$ and $c-G t H$

\begin{tabular}{|c|c|c|c|c|c|}
\hline Preparation & $\mathrm{Kd}$ & $\mathrm{PM}_{\mathrm{G100}}$ & $\mathrm{Ks}_{20 \mathrm{~W}}$ & $\mathrm{PMI}_{20 \mathrm{~W}}$ & $\begin{array}{c}\text { Mobility } \\
\text { electrophoretic }\end{array}$ \\
\hline & $\ldots$ & & -...- & $\ldots$ & $\cdots$ \\
\hline $\mathrm{t}-\mathrm{GtH}_{1}$ & 0.29 & 27500 & 1.40 & 15500 & $0.31-0.41-0.45$ \\
\hline $\mathrm{t}-\mathrm{GtH}_{2}$ & 0.29 & 27500 & 2.45 & 28500 & $0.50+0.58$ \\
\hline $\begin{array}{c}\text { c-GtH } \\
\text { BURZAWA (1973) }\end{array}$ & 0.280 & 27000 & 2.67 & $2 \times 500$ & $0.50-0.54$ \\
\hline $\begin{aligned} & \mathrm{Kd}: \text { exclusio } \\
& \mathrm{PM}_{\mathrm{G100}}: \text { Appare } \\
& \mathrm{KS}_{20 \mathrm{~W}}: \text { Sedimer } \\
& \mathrm{PM}_{20 \mathrm{~W}}: \text { Apparer }\end{aligned}$ & $\begin{array}{l}\text { ient on } \\
\text { ular we } \\
\text { oefficie } \\
\text { ular we }\end{array}$ & $\begin{array}{l}\text { dex } G_{G}-10 \\
\text { etermined } \\
\text { analytica } \\
\text { btained } w\end{array}$ & $\begin{array}{l}\text { ephadex } \\
\text { acentrif } \\
\text { quilibriu }\end{array}$ & $\begin{array}{l}00 \\
\text { on } \\
\text { tra-cent }\end{array}$ & ion. \\
\hline
\end{tabular}


Amino acid compositions of $\mathrm{t}-\mathrm{GtH}_{1}$ and $\mathrm{t}-\mathrm{GtH}_{2}$ are given in table 5 and compared to values obtained by BURzAWA-GERARD (I973) on c-GtH.

Compositions, expressed in residues/Ioo amino acid residues, are comparable from one preparation to another. Comparison of the numbers of residues/mole for $t-\mathrm{GtH}_{2}$ and c-GtH (I60-168) shows large differences, mainly in valine and tyrosine, and many similarities : arginine, glutamic acid, glycine, alanine, hemicystine, phenylalanine. Between the two preparations of $\mathrm{t}-\mathrm{GtH}$ the number residues per mole increases from $\mathrm{I} 25$ for $\mathrm{t}-\mathrm{GtH}_{1}$ to $\mathrm{I} 60$ for $\mathrm{t}-\mathrm{GtH}_{2}$.

The ultraviolet absorption spectra presents a maximum at $276 \mathrm{~m} \mu$, characteristic of tyrosinized protein.

TABLE 5

Amino acid composition of trout and carp gonadotropic hormones

\begin{tabular}{|c|c|c|c|c|c|c|}
\hline \multirow{2}{*}{$\begin{array}{c}\text { Hormone } \\
\text { AA }\end{array}$} & \multicolumn{2}{|c|}{$\mathrm{t} \cdot \mathrm{G} \mathrm{tH}_{1}$} & \multicolumn{2}{|c|}{$\mathrm{t}-\mathrm{G} \mathrm{tH}_{2}$} & \multicolumn{2}{|c|}{$\begin{array}{c}\text { c-GtH } \\
\text { BURZAWA GERARD }(1973)\end{array}$} \\
\hline & $\begin{array}{l}\text { residues/ } \\
\text { mole }\end{array}$ & $\begin{array}{c}\text { residues/ } \\
100 \text { residues }\end{array}$ & $\begin{array}{l}\text { residues/ } \\
\text { mole }\end{array}$ & $\begin{array}{l}\text { residues/ } \\
\text { 101/ residues }\end{array}$ & $\begin{array}{l}\text { residues/ } \\
\text { mole }\end{array}$ & $\begin{array}{c}\text { residues/ } \\
100 \text { residues }\end{array}$ \\
\hline Lysine & 4.68 & 3.74 & 9.80 & 5.69 & 11.3 & 6.7 \\
\hline Histidine .... & 3.11 & 2.48 & 6.3 & 3.65 & 5,4 & 3.2 \\
\hline Arginine $\ldots .$. & 4.46 & 3.56 & 6.9 & 4.00 & 7.0 & 4.1 \\
\hline Aspartic acid ..... & 14.32 & 11.45 & 17.76 & 10.3 & 14 & 8.4 \\
\hline Threonine ........ & 11.23 & 8.98 & 15.19 & 8.8 & 13 & 7.7 \\
\hline Serine $\ldots \ldots \ldots \ldots$ & 8.35 & 6.67 & 8.88 & 5.10 & 11.5 & 6.8 \\
\hline Glutamic acid...... & 15.74 & 12.58 & 15.75 & 9.10 & 15.5 & 9.2 \\
\hline Proline . . . . . . . . . & 11.61 & 9.28 & 11.6 & 6.74 & 14 & 8.3 \\
\hline Glycine ......... & 6.06 & $4.8 / t$ & 7.0 & 4.30 & 6.5 & 3.9 \\
\hline Alanine ......... & 3.57 & 2.85 & 5.79 & 3.36 & 6.4 & 3.8 \\
\hline Hemicystine $\ldots$. & 11.38 & 9.09 & 12.03 & 6. 97 & 11.5 & 6.9 \\
\hline Valine ......... & 8.89 & 7.08 & 12.0 & 7.09 & 19.4 & 11.5 \\
\hline Methionine ....... & 2.02 & 1.81 & 3.70 & 2.15 & 2.6 & 1.5 \\
\hline Isolencine $\ldots \ldots \ldots$ & 4.92 & 3.98 & 7.11 & 5.06 & 4.8 & 2.8 \\
\hline Leucine . . . . . . . & b. 98 & 5.58 & 10 & 5.79 & 12.5 & 7.4 \\
\hline Tyrosine ........ & 3.82 & 8.05 & 1.97 & 2.88 & 8.1 & 4.8 \\
\hline Phenylalanine .... & 3.97 & 3.17 & 5.4 & 3.13 & 6.7 & 2.8 \\
\hline N. residues/mole & 125 & & 160 & & 168 & \\
\hline
\end{tabular}

\section{DISCUSSION}

With the techniques described, a gonadotropic hormone ( $t-\mathrm{G} t \mathrm{H}$ ) has been obtained from trout pituitary which is 67 times more active than the crude pituitary acetonic powder. The ponderal yield is $0.14 \mathrm{p}$. Ioo. This technique resembles those used by BURZAWA-GERARD (I97I) for carp gonadotropic hormone and by DoNALISON et al. (I972) for the salmon one (s-GtH).

The physico-chemical characteristics of the three hormones are similar as regards molecular weight determined on Sephadex G-roo, sedimentation coefficients and molecular weight determined by equilibrium ultracentrifugation. The constants are compa- 
rable to those of o. LH and o.FSH (PAPKoFf, I97I ; CAHILI and HART, I969). As do carp and salmon hormones, trout gonadotropin gives two strips of similar mobility in polyacrylamide gel electrophoresis characteristic of a molecular polymorphism (BRASELTON and McShaN, I970 ; CourTE, I970). If the $t-\mathrm{GtH}_{1}$, obtained after chromatography on DEAE-cellulose in absence of dithiothreitol, and $\mathrm{t}-\mathrm{GtH}_{2}$ (the most completely purified) have the same molecular weight determined on Sephadex G-Ioo, they behave very differently with ultracentrifugation. Biological activity of the $\mathrm{t}-\mathrm{GtH}_{1}$ decreases after chromatography on DEAE-C in comparison to the preceding purification stage. Mammalian hormones, $\mathrm{LH}$ and FSH, may be dissociated into two sub-units, $\alpha$ and $\beta$ (LI and StARMan, I964; PAPKOFF and EKBLAD, I970), having a molecular weight of about I5 000, possessing KS of about I.5 without biological activity. BURZAWA-GERARD (I97I) also observed that after 15 hours of ultracentrifugation in saccharose gradient at 65000 r.p.m., the sedimentation peak at TS 2.67 of native c-GtH gives a second fraction of TS r.62 without biological activity, having a molecular weight of 15800 . This author thus suspected spontaneous dissociation of c-GtH, which was confirmed by her later studies (BURZAWA-GERARD, I975).

The characteristics of $\mathrm{t}_{-\mathrm{GtH}_{1}}$ (KS : I.4; equilibrated molecular weight of sedimentation 15.500 ; drop in biological activity) leads us to suppose that this trout gonadotropic preparation was obtained in a partially dissociated state, dissociation being completed during ultracentrifugation. The t-GtH would present no differences in quaternary structure (dissociation into sub-units) as compared to other glycoprotein hormones, such as 'TSH, LH, FSH, and c-GtH.

It also seems that dissociation could be spontaneous for both $\mathrm{t}-\mathrm{GtH}$ and c-GtH. Fish gonadotropic hormones are thus more fragile than mammalian gonadotropins.

Ending purification at the DEAE-cellulose chromatography stage (DONALDSON et al., I972) seems insufficient to obtain pure hormone. Amino acid composition analysis of the preparation obtained after this stage gives an overall composition of I25 residues per mole, corresponding to $50 \mathrm{p}$. 100 of the molecular weight. On the other hand, after ultrogel $\mathrm{ACA}_{54}$ chromatography, the number of residues per mole increases to 160 , representing $70 \mathrm{p}$ Ioo of hormone weight. This values is similar to that obtained by BURZAWA-GERARD (1973) for c-GtH (I68 residues/mole). We have equivalent results (BRETON et al., 1975) comparing two c-GtH preparations obtained according to BURZAWA-GERARD's technique after DEAE-cellulose (I) and G-IOo post-DEAE-cellulose (2) chromatographies.

A comparison of the numbers of residues of each amino acid for t-GtH and c-GtH reveals notable differences which, besides a different sequence, may explain immunological and biological specificity of fish gonadotropins. These values are also different from those obtained for mammalian LH and FSH. Analysis of carbohydrate and sialic acid contents in the protein obtained could not be done, the amounts procured being too small.

In conclusion, trout pituitary gonadotropin was obtained with a sufficiently good degree of homogeneity to allow the radioimmunological determination of this hormone in the plasma of the Trout (BRETon et al., unpublished data). This hormone has physico-chemical characteristics comparable to corresponding fish c-GtH and s-GtH hormones and to mammalian $\mathrm{L} / \mathrm{H}$ and $\mathrm{FSH}$. 


\section{ACKNOWLEDGEMENTS}

We wish to thank Mr. Pernollet and Mr. Garnier (Laboratoire de Biochimie physique, I. N. R. A.) who performed analytical ultracentrifugations, and Mr. MArchelidon (Laboratoire de Physiologie comparée du Muséum d'Histoire Naturelle) and Mr. Menezo (Laboratoire de Biologie, I. N. S. A., Villeurbanne). who helped us in assays of amino acid composition of our preparations.

Mrs. DAIFUKU is acknowledged for the translatation of this manuscript.

We also wish to thank I. N. R. A. and the C.N.R.S. (A. T. P. Physiologie ecologique, contract $n^{\circ} 449909$ ) who gave funds for this work.

\section{RÉSUMÉ}

\section{PURIFICATION D'UNE HORMONE GONADO'TROPE \\ HYPOPHYSAIRE, DE LA TRUITE ARC-EN-CIEI, (SALMO GAIRDNERII RICHARDSON)}

Une méthode de purification d'une hormone gonadotrope de Truite est proposée. La technique comprend les étapes suivantes : une extraction alcoolique, deux gel filtrations successives sur Séphadex G-5o et G-1oo, une chromatographie sur DEAE-cellulose et une chromatographie sur ultrogel ACA54. L'activité biologique des fractions obtenues a été mesurée en utilisant le test de maturation des ovocytes de Truite in vitro.

La préparation obtenue présente un poids moléculaire d'environ 27500 déterminé par comportement sur Séphadex G-1oo et ultracentrifugation analytique pour un $\mathrm{KS}_{20}$ de 2,45 . L'électrophorèse sur gel de polyacrylamide révèle la présence de deux bandes de mobilité électrophorétique $0,5^{\circ}$ et $0,5^{8}$. L'analyse de la composition en acides aminés de la préparation indique un nombre de résidus 160 AA par mole.

Ces différentes valeurs sont comparées aux valeurs correspondantes pour la c-GtH, la s-GtH et les gonadotropines mammaliennes.

\section{RÉFÉRENCES}

Billard R., Burzawa-Gerard F., Breton B., 1970. Régénération de la spermatogenèse du Cyprin hypophysectomisé Carassius auratus L. par un facteur gonadotrope hautement purifié de Carpe. C. R. Acad. Sci., 272, $98 \mathrm{I}-983$.

Braselton W. E., McShan W. H., i97o. Purification and properties of follicle stimulating and luteinizing hormones from horse pituitary glands. Arch. Biochem., 139, 45-58.

Breton B., Billard R., Jalabert B., 1973. Spécificité d'action et relations immunologiques des hormones gonadotropes de quelques téléostéens. Ann. Biol. anim. Bioch. Biophys., 13, 347-362.

Breton B., Reinaud P., I975. Données non publiées.

Burzawa-Gerard E., 197i. Purification d'une hormone gonadotrope hypophysaire d'un poisson téléostéen la Carpe (Cyprinus carpio L.). Biochimie., 53, 545-552.

Burzawa-Gerard E., Fontaine Y. A., r972. The gonadotropins of lower vertebrates. Gen. Comp. Endocr., suppl., 3, 7I5-728.

Burzawa-Gerard E., I973. Étude biologique et biochimique de l'hormone gonadotrope d'un poisson téléostéen, la Carpe (Cyprinus carpio L.). Thèse, Paris. $124 \mathrm{p}$.

Burzawa-Gerard E., 1975. Séparation et réassociation des sous-unités de l'hormone gonadotrope d'un poisson téléostéen, la Carpe (Cyprinus carpio L.). C. R. Acad. Sci., 278, D, r681-I684.

CAHILI C. L., HART K. M., rg69. Sedimentation velocity and equilibrium characteristics of ovine follicule stimulating hormone. Biochim. Biophys. Acta., 194, 227-233. 
Clemens H. P., Cieresko L. S., Shoemakrr J. D., Grant F. B., ig64a. Partial characterisation of the gonadal hydratation principle in pituitary of Carp. Gen. Comp. Endocr., 4, 503-507.

Clemens H. P., Grant F. B., 1964 b. Gonadal hydratation of Carp and goldfish after injections of pituitary extracts. Zoologica, 49, 193-210.

Courte C., 1970. Isolement, études physico-chimiques et biologiques de l'hormone lutéinisante de trois espèces de mammifères : le Mouton, le Bouf et le Ra!. Thèse, Paris.

Donaldson E. M., Yamazaki F., Dye H. M., Philleo W. W., 1972. Preparation of gonadotropin from Salmon (Onchorynchus tschareytscha) pituitary glands. Gen. Comp. Endocr., 18, 469-48I.

Donaldson E. M., Funk J. D., Withler F. C., Morley R. B., I972. Fertilization of pink Salmon (Oncorhynchus gorbuscha) ova by spermatozoa from gonadotropin injected juveniles. $J$. Fish. Res. Bd. Canada., 29, $13^{-18 .}$

Fontaine Y. A., Salmon C., Fontatne-Bertrand E., Burzawa-Gerard E., Donaldson E. M., I972. Comparison of the activities of two purified fish gonadotropins on adenyl cyclase activity in the goldfish ovary. Can. J. Zool., 50, I673-1676.

Gontcharov B. F., 1972. Experiment to determine the gonadotropic activity of the hypophysis of sturgeons by maturation of oocytes in vitro. Trudy Centr. Lab. Prod. Fish. stock, Glavrybood Fish. Minist. U.R.S.S.

Jalabert B., Breton B., Billard R., I974. Dosage biologique des hormones gonadotropes de poissons par le test de maturation in vitro des ovocytes de Truite. Ann. Biol. anim. Bioch. Biophys., 14,2 I $7-228$.

Laurent T. C., Killander J., I964. A theory of gel filtration and its experimental verification. J. Chromatogr., 14, 317-330.

Li C. W., Starman B., 1964. Molecular weight of sheep pituitary interstitial cell stimulating hormone. Nature (Lond.)., 202, $291-292$.

Lowry O. H., Rosenbrough N. S., Farr A. L., Randall R. S., I95I. Protein measurement with the folin phenol reagent. J. Biol. Chem., 193, 265-275.

Menezo Y., r973. Les composés azotés des sécrétions tubulaires et utérines chez la Brebis en œestrus. Comparaison avec le liquide séminal et le plasma sanguin. Sperm transport and fertilizing ability. INSERM., 26, 389-406.

Moore S., Spackman D. H., Stein W. H., i958. Chromatography of amino acids on sulfonated polystyrene resins. An improved system. Ann. Chem., 30, i $85^{- \text {I }}$ 190.

Ornstein L., 1974. Disc electrophoresis. I. Background and theory. Ann. N. I., Acad. Sci., 121, 321.

PapkofF H., EквLAD M., I970. Ovine follicle stimulating hormone : preparation and characterisation of its subunits. Biochem. Biophys. Res. Commun., 40, 614-62I.

PAPKofF H., I97ז. The subunit nature of interstitial cell stimulating hormone and follicule stimulating hormone. In structure-activity relationships of protein and polypeptide hormones. Excerpia medica., 241, 73-79.

Schmidt P. J., Mitchell B. S., Smith M., Tsuyukl H., r965. Pituitary hormones of the pacific salmon. I. Response of gonad in immature trout (Salmo gairdnerii) to extract of pituitary glands from adult pacific salmon (Oncorhynchus). Gen. Comp. Endocr., 5, 197-206.

Sundararaj B. J., Anand T. C., Donaldson E. M., 1972. Effect of partially purified salmon pituitary gonadotropin on ovarian maintenance ovulation and vitellogenesis in the hypophysectomized catfish (Heteropneustes fossilis) (BLoch). Gen. Comp. Endocr., 17, 570-573.

Yamazaki F., Donaldson E. M., rg68. The spermiation of goldfish Carassius auratus as a bioassay for salmon (Oncorhynchus tschawytscha) gonadotropin. Gen. Comp. Endocr., 10, 38,3-391. 